\title{
KUALITAS FISIK TELUR ASIN ITIK PEGAGAN YANG DIPROSES DENGAN MENGGUNAKAN ABU PELEPAH KELAPA SAWIT DAN ASAP CAIR
}

\section{THE PHYSICAL QUALITY OF SALTED PEGAGAN DUCK EGG USING PALM OIL FRONDS ASH AND LIQUID SMOKE AS AN CURING AGENT}

\author{
Fitra Yosi*, Nurul Hidayah, Jurlinda, dan Meisji Liana Sari \\ Program Studi Peternakan, Fakultas Pertanian, Universitas Sriwijaya, Indralaya, 30662
}

Submitted: 10 December 2015, Accepted: 4 February 2016

\section{INTISARI}

Asap cair merupakan bahan yang bermanfaat untuk digunakan dalam proses pengawetan telur. Tujuan penelitian ini adalah untuk mengetahui pengaruh penggunaan abu pelepah sawit dan asap cair dalam proses pengasinan terhadap kuaitas fisik telur itik pegagan. Rancangan penelitian yang digunakan adalah Rancangan Acak Lengkap (RAL) pola searah yang terdiri atas 5 perlakuan dan 4 ulangan dengan setiap ulangan terdiri 5 butir. Perbedaan mean diuji dengan Duncan Multiple Ranges Test. Perlakuan terdiri atas R0, R1, R2, R3, dan R4, di mana seluruhnya menggunakan abu pelepah kelapa sawit dan garam dapur $(1: 0,25)$ serta masing-masing ditambahkan larutan asap cair secara berurutan $0 \%$ (kontrol), $2,5 \%$, $5 \%, 7,5 \%$, dan $10 \%(\mathrm{v} / \mathrm{v})$. Variabel yang diamati adalah kualitas fisik telur asin, meliputi susut bobot telur, berat kuning telur, berat putih telur, indeks kuning telur, indeks putih telur, berat kerabang telur, tebal kerabang telur, kedalaman rongga udara, warna kuning telur, $\mathrm{pH}$ kuning telur, $\mathrm{pH}$ putih telur, haugh unit (HU), viskositas putih telur. Hasil penelitian menunjukkan bahwa penggunaan abu pelepah kelapa sawit dan asap cair dalam proses pengasinan berpengaruh nyata $(P<0,05)$ terhadap tebal kerabang telur, kedalaman rongga udara, berat putih telur, berat kerabang telur, $\mathrm{pH}$ putih telur, indeks putih telur, haugh unit $(\mathrm{HU})$, viskositas putih telur, dan susut bobot telur, akan tetapi berpengaruh tidak nyata $(P>0.05)$ terhadap warna kuning telur, $\mathrm{pH}$ kuning telur, berat kuning telur, dan indeks kuning telur. Kesimpulan penelitian adalah penggunaan abu pelepah kelapa sawit dan asap cair dalam proses pengasinan dapat mempertahankan kualitas fisik telur asin itik pegagan.

(Kata kunci: Abu pelepah kelapa sawit, Asap cair, Kualitas fisik, Telur itik pegagan)

\section{ABSTRACT}

Liquid smoke is a useful material for use in the process of preserving eggs. The purpose of this study was to determine the effect for use of palm oil fronds ash and liquid smoke in the process of salting to the physical quality of pegagan duck's egg. This study was assingned in a Completely Randomized Design, which consists of 5 treatments and 4 replications. Each replicatation used as much as 5 eggs. The treatment consists of R0, R1, R2, R3, and R4, where all of treatments used palm oil fronds ash and salt (1:0.25) and each treatment was added liquid smoke $0 \%$ (control), 2,5\%,5,0\%, 7,5\%, and $10 \%(\mathrm{v} / \mathrm{v})$, respectively. The experimental variabel observed were egg weight loss, yolk and albumen weight, yolk and albumen index, eggshell weight, eggshell thickness, the depth of air cavity, yolk color, $\mathrm{pH}$ yolk adn albumen $\mathrm{pH}$, Haugh units (HU), albumen viscosity. Data were subjected to analysis of variance and significantly different followed by Duncan's multiple range test at 5\%. The results showed that the use of palm oil fronds ash and liquid smoke in the process of salting significantly affected $(P<0.05)$ the eggshell thickness, depth of air cavity, albumen weight, eggshell weight, albumen $\mathrm{pH}$, albumen index, haugh units (HU), albumen viscosity, and egg weight loss, but not significantly affected $(P>0.05)$ the yolk color, yolk $\mathrm{pH}$, yolk weight, and yolk index. It was concluded that the use of palm oil fronds ash and liquid smoke in the salting process can maintain the physical quality of salted pegagan duck egg.

(Key words: Liquid smoke, Palm oil fronds ash, Pegagan duck eggs, Physical quality)

\footnotetext{
${ }^{*}$ Korespondensi (corresponding author):

Telp. +62 85220286664

E-mail: fitrayosi@unsri.ac.id
} 


\section{Pendahuluan}

Itik pegagan merupakan salah satu plasma nutfah ternak asal Sumatera Selatan yang banyak dibudidayakan oleh peternak sebagai penghasil telur. Telur merupakan salah satu produk peternakan yang banyak dikonsumsi oleh masyarakat karena selain murah telur juga mengandung zat nutrisi yang tinggi. Diketahui bahwa dalam satu butir telur itik segar terkandung protein $13,10 \%$, lemak $14,30 \%$, karbohidrat $0,8 \%$, dan abu $1 \%$ (Winarno dan Koswara, 2002). Di samping kaya zat gizi, telur juga sangat mudah mengalami penurunan kualitas terutama pada saat dilakukan penyimpanan.

Guna mempertahankan kualitas telur selama penyimpanan, maka diperlukan teknologi pengawetan. Salah satu teknologi pengawetan yang sudah dikenal adalah proses pengasinan. Di samping untuk pengawetan, pengasinan juga dapat meningkatkan cita rasa pada telur, yaitu timbulnya rasa masir pada kuning telur (Wulandari, 2004). Hal inilah yang kemudian membuat telur asin semakin disukai oleh masyarakat. Bahan yang umumnya digunakan dalam proses pengasinan telur adalah garam dapur. Penggunaan garam dapur dalam proses pengasinan telur disamping memiliki keuntungan seperti sebagai antiseptik dan pengendali mikroorganisme penyebab kebusukan, juga memiliki kelemahan yaitu dapat menganggu kesehatan apabila mengonsumsi garam dapur $(\mathrm{NaCl})$ secara berlebihan. Oleh karena itu, perlu diupayakan bahan alternatif untuk mengurangi penggunaan garam dapur tersebut. Bahan yang diduga berpotensi untuk mengurangi penggunaan garam dapur adalah abu pelepah kelapa sawit. Diketahui bahwa abu pelepah kelapa mengandung beberapa unsur penyusun garam, seperti magnesium $(\mathrm{Mg})$ dan kalium (K), di mana kedua unsur tersebut diyakini dapat membuat rasa asin pada telur selama dengan cara membentuk garam $\mathrm{MgCl}$ dan $\mathrm{KCl}$. Di Sumatera Selatan, potensi untuk memanfaatkan pelepah kelapa sawit sendiri masih sangat besar. Hal ini mengingat kelapa sawit merupakan salah satu komoditas andalan di Sumatera Selatan.

Bahan lain yang juga diyakini dapat mempertahankan kualitas telur dalam proses pengasinan adalah asap cair. Hal ini dikarenakan asap cair mengandung senyawa fenol dan asam-asam organik yang berfungsi menyelubungi dan melindungi pori-pori kerabang telur sehingga penguapan gas dan uap air dari dalam telur dapat dikurangi dan pertumbuhan mikroba dapat dikontrol (Nursiwi et al., 2013; Yosi et al., 2015). Asap cair merupakan hasil dari proses dispersi asap kayu dalam air yang dibuat dengan mengkondensasikan asap hasil pirolisis kayu (Yulistiani dan Purnama, 1997). Selama ini, informasi tentang pemanfaatan asap air dalam proses pengasinan telur masih terbatas, oleh karena itu tujuan penelitian ini adalah untuk mengetahui pengaruh penggunaan abu pelepah kelapa sawit dan asap cair dalam proses pengasinan terhadap kualitas fisik telur.

\section{Materi dan Metode}

\section{Materi}

Bahan yang digunakan adalah telur itik pegagan yang masih segar (umur 1-3 hari) sebanyak 100 butir yang diperoleh dari peternakan itik pegagan di Desa Kota Daro, Ogan Ilir, Sumatera Selatan. Bahan lain yang digunakan adalah asap cair dan abu pelepah kelapa sawit. Adapun komposisi zat kimia yang terkandung di dalam asap cair dapat dilihat pada Tabel 1, sementara kandungan mineral dalam abu pelepah kelapa sawit disajikan pada Tabel 2. Alat yang digunakan dalam penelitian adalah wadah telur, spatula, gelas kimia, kaca datar, timbangan digital merk Ohauss dengan ketelitian $0,01 \mathrm{~g}$, viskometer/viskotester, $\mathrm{pH}$ meter, jangka sorong, cawan petridis, dan thermometerhigrometer digital, micrometer scrub, dan tripodmicrometer.

\section{Metode}

Tahap 1. Preparasi telur. Pertamatama, telur itik pegagan yang masih segar (umur 1-3 hari) dikumpulkan. Kemudian semua telur dicuci dengan air mengalir dan ditiriskan dalam wadah telur.

Tahap 2. Pembuatan adonan abu pelepah kelapa sawit dan larutan asap cair. Pertama-tama, abu pelepah kelapa sawit dihaluskan dan disaring sampai diperoleh abu yang halus. Kemudian, buat larutan asap cair yang terdiri atas 5 level, yaitu $0 ; 2,5 ; 5, ; 7,5$; dan $10 \%(\mathrm{v} / \mathrm{v})$, yaitu dengan cara melarutkan asap cair ke dalam air. Setelah itu, campurkan sedikit demi sedikit abu pelepah kelapa sawit 
Tabel 1. Beberapa senyawa yang terkandung dalam asap cair (some of compounds contained in liquid smoke)

\begin{tabular}{lc}
\hline \multicolumn{1}{c}{ Senyawa (compounds) } & Konsentrasi (\%) (concentration (\%)) \\
\hline Acetic acid (CAS) Ethylic acid & 13.31 \\
Formic acid (CAS) Bilorin & 12.27 \\
Propanedioic acid (CAS) Malonic acid & 21.06 \\
2-Propanone, 1-hydroxy- (CAS) Acetol & 5.57 \\
Acetic acid (CAS) Ethylic acid & 14.63 \\
(E)-Hex-2-en-4ynal & 27.91 \\
Phenol, 2-methoxy- (CAS) Guaiacol & 3.91 \\
2-Methoxy-4-methylphenol & 0.99 \\
2,5-Dimethoxytoluene & 0.35 \\
\hline
\end{tabular}

Tabel 2. Kandungan mineral kalium (K), magnesium (Mg), dan klorida (Cl) dalam abu pelepah sawit

(the mineral content of potassium (K), magnesium (Mg), and chloride (Cl) in palm oil fronds ash)

\begin{tabular}{cc}
\hline \hline Mineral & Konsentrasi (\%) (concentration (\%)) \\
\hline $\mathrm{K}$ & 10,00 \\
$\mathrm{Mg}$ & 0,13 \\
$\mathrm{Cl}$ & 0,50 \\
\hline
\end{tabular}

dengan larutan asap cair dan diaduk hingga membentuk adonan yang kental yang dapat melekat pada kulit telur.

Tahap 3. Pembuatan telur asin. Telur itik pegagan kemudian dibungkus atau dibalut satu per satu dengan adonan tersebut sampai menyerupai bola yang cukup digenggam dengan kedua telapak tangan. Telur yang telah dibalut adonan ditempatkan dalam bak plastik dan diperam selama 2 minggu. Setelah waktu pemeraman selesai, telur asin dipanen dan dibersihkan dari adonan yang menempel, kemudian dicuci sampai bersih.

Tahap 4. Analisis kualitas telur asin. Telur yang telah disimpan sesuai dengan perlakuan kemudian dianalisis berdasarkan peubah yang telah ditentukan dengan metode masing-masing.

Variabel yang diamati yaitu susut berat telur, berat putih dan kuning telur, tebal kerabang, berat kerabang telur, kedalaman rongga udara, indeks putih telur, indeks kuning telur, $\mathrm{pH}$ putih dan kuning telur, viskositas putih telur, haugh unit (HU), dan warna kuning telur.

Susut bobot telur. Setelah pemeraman selama 14 hari, adonan yang menempel pada masing-masing telur dibersihkan lalu ditimbang dengan menggunakan timbangan digital. Susut bobot telur diperoleh dengan cara mengurangkan berat awal dengan berat akhir.

Berat putih dan kuning telur. Pertama-tama, kerabang telur dipecahkan dengan hati-hati. Putih dan kuning telur lalu dikeluarkan dari dalam kerabang dan diletakkan di atas sebuah kaca datar. Putih dan kuning telur kemudian dipisahkan dengan menggunakan spatula. Putih dan kuning telur diletakkan di cawan petridish secara terpisah lalu diukur dengan menggunakan timbangan digital.

Tebal kerabang. Telur dipecahkan dengan hati-hati kemudian bagian kerabang telur di ujung tumpul, tengah, dan ujung runcing diambil dan diukur dengan menggunakan micrometer scrub. Tebal kerabang telur diukur dengan menggunakan rumus sebagai berikut (Ramanoff dan Ramanoff, 1963):

$$
\mathrm{TK}=\frac{\mathrm{t} 1+\mathrm{t} 2+\mathrm{t} 3}{3}
$$

Di mana: $\mathrm{TK}=$ tebal kerabang; $\mathrm{t} 1, \mathrm{t} 2$, dan $\mathrm{t} 3$ $=$ tebal kerabang pada ujung tumpul, tengah, dan runcing.

Berat kerabang telur. Kerabang telur dipecahkan dengan hati-hati. Putih dan kuning telur lalu dikeluarkan dari dalam kerabang dan diletakkan di dalam cawan petridish. Kerabang telur kemudian disimpan dan didiamkan selama 24 jam. Setelah itu, kerabang telur ditimbang dengan menggunakan timbangan digital merk Ohauss dengan ketelitian 0,01 g dan dicatat hasilnya. Persentase berat kerabang dihitung dengan membagi berat kerabang dengan berat telur dikalikan 100\% (Sihombing et al., 2006) 
Kedalaman rongga udara. Telur dipecahkan dengan hati-hati kemudian kerabang telur yang bagian ujung tumpul dipisahkan. Selanjutnya kedalaman rongga udara diukur dengan menggunakan jangka sorong, yaitu dari membran dalam kerabang yang berpisah dengan membran kerabang bagian luar hingga kerabang (Jazil et al., 2013).

Indeks putih telur. Sebutir telur diambil lalu dipecahkan dengan hati-hati. Putih dan kuning telur dikeluarkan dan diletakkan di atas sebuah kaca datar. Tinggi putih telur kental, lebar dan panjang putih telur masing-masing diukur dengan menggunakan tripodmicrometer dan jangka sorong. Nilai indeks putih telur dihitung dengan cara membandingkan tinggi putih telur kental dengan rerata panjang dan lebar putih telur (Sihombing et al., 2006)

Indeks kuning telur. telur dipecahkan dengan hati-hati. Putih dan kuning telur lalu dikeluarkan dan diletakkan diatas sebuah kaca datar. Tinggi dan diameter kuning telur kemudian diukur dengan menggunakan jangka sorong. Pengukuran indeks kuning telur dilakukan menurut Sirait (1986), yaitu dengan cara membandingkan tinggi kuning telur dengan diameter kuning telur.

pH kuning dan putih telur. Pengukuran $\mathrm{pH}$ dilakukan menurut Iza et al. (1985). $\mathrm{pH}$ telur dihitung dengan mencelupkan ujung elektroda $\mathrm{pH}$ meter pada putih telur yang telah dipecah dan pada kuning telur yang telah dilarutkan dalam aquades. Sebelum pengukuran, alat $\mathrm{pH}$ meter terlebih dahulu dikalibrasi dengan cairan buffer $\mathrm{pH} 4$ dan $\mathrm{pH} 7$.

Viskositas putih telur. Kerabang telur dipecahkan dengan hati-hati. Putih dan kuning telur dikeluarkan dari dalam kerabang kemudian diletakkan diatas sebuah kaca datar. Putih telur dipisahkan dari kuning telur dengan menggunakan spatula. Setelah itu, putih telur dimasukkan ke dalam gelas kimia sebanyak $100 \mathrm{ml}$ lalu diukur viskositasnya dengan cara memasukkan alat pemutar dari alat viskomester. Pengukuran viskositas ini dilakukan menurut AOAC (1984).

Haugh unit (HU). Pertama-tama, telur ditimbang beratnya lalu dipecahkan secara hati-hati dan diletakkan diatas kaca datar. Selanjutnya tinggi putih telur kental diukur dengan tripodmicrometer. Pengukuran haugh unit dilakukan dengan rumus:

$$
\mathrm{HU}=100 \log \left(\mathrm{H}+7,57-1,7 \mathrm{~W}^{0,37}\right)
$$

Di mana: $\mathrm{HU}=$ haugh unit; $\mathrm{H}=$ tinggi putih telur kental $(\mathrm{mm}) ; \mathrm{W}=$ berat telur $(\mathrm{g})$.

Warna kuning telur. Telur dipecahkan dengan hati-hati. Putih dan kuning telur lalu dikeluarkan dari dalam kerabang dan diletakkan di atas cawan petridish. Warna kuning telur diukur dengan menggunakan Roche Egg Yolk Color Fan, yaitu dengan membandingkan warna kuning telur dengan warna kuning pada kipas Roche.

Rancangan penelitian yang digunakan adalah Rancangan Acak Lengkap pola searah yang terdiri atas 5 perlakuan dan 4 ulangan. Masing-masing ulangan digunakan sebanyak 5 butir telur itik. Perlakuan terdiri atas R0, R1, R2, R3, dan R4, di mana seluruhnya menggunakan abu pelepah kelapa sawit dan garam dapur (1:1/4) serta masing-masing ditambahkan larutan asap cair secara berurutan $0 \%$ (kontrol), 2,5\%, 5\%, $7,5 \%$, dan $10 \%(\mathrm{v} / \mathrm{v})$. Data hasil pengamatan dianalisis dengan ANOVA menggunakan SPSS 17. Apabila hasil yang diperoleh berpengaruh nyata, maka dilakukan uji lanjut dengan menggunakan Uji Jarak Berganda Duncan (Steel dan Torrie, 1993).

\section{Hasil dan Pembahasan}

\section{Suhu dan kelembaban udara di ruangan pemeraman telur}

Selama proses penelitian, dilakukan pengukuran terhadap suhu dan kelembaban udara di tempat pemeraman telur asin. Suhu dan kelembaban udara selama pemeraman perlu untuk diketahui karena merupakan faktor yang dapat mempengaruhi proses penguapan uap air dari dalam telur sehingga menentukan kualitas telur (Wulandari, 2004). Adapun kisaran suhu dan kelembaban udara di tempat pemeraman telur asin disajikan pada Tabel 3. Suhu udara tertinggi terjadi pada siang hari, yaitu $31,2{ }^{\circ} \mathrm{C}$, sedangkan yang terendah terjadi pagi hari, yaitu $24,3^{\circ} \mathrm{C}$. Sementara itu, kelembaban udara tertinggi terjadi pada sore hari, yaitu $84 \%$ dan terendah pada pagi hari yaitu $63 \%$.

\section{Kualitas fisik telur asin itik pegagan}

Kualitas fisik telur asin itik pegagan hasil proses pengasinan dengan abu pelepah kelapa sawit dan asap cair dapat dilihat pada Tabel 3 . Berdasarkan analisis ragam, diperoleh hasil bahwa pemanfaatan abu pelepah kelapa sawit dan asap cair berpengaruh nyata $(P<0.05)$ terhadap tebal kerabang telur, kedalaman 
Tabel 3. Kisaran suhu dan kelembaban udara di ruangan pemeraman telur (the range of air temperature and humidity in the egg storage room)

\begin{tabular}{lccc}
\hline \hline Komponen (component) & $\begin{array}{c}\text { Pagi (morning) } \\
\text { (pkl. 08.00-09.00 WIB) } \\
(\text { at 08.00-09.00 a.m.) }\end{array}$ & $\begin{array}{c}\text { Siang (noon) } \\
\text { (pkl. 12.00-13.00 WIB) (at } \\
12.00 \text { a.m }-01.00 \text { p.m.) }\end{array}$ & $\begin{array}{c}\text { Sore (afternoon) } \\
\text { (pkl. 16.00-17.00 WIB) } \\
\text { (at 04.00-05.00 p.m.) }\end{array}$ \\
\hline $\begin{array}{l}\text { Suhu udara }\left({ }^{\circ} \mathrm{C}\right) \\
\text { (air temperature }\left({ }^{\circ} \mathrm{C}\right) \text { ) }\end{array}$ & $24,3-29,8$ & $27,4-31,2$ & $28,7-30,2$ \\
$\begin{array}{l}\text { Kelembaban udara }(\%) \\
\text { (air humidity }(\%))\end{array}$ & $63-75$ & $64-81$ & $53-84$ \\
\hline
\end{tabular}

Tabel 4. Kualitas fisik telur asin itik pegagan menggunakan abu pelepah kelapa sawit dan asap cair (the physical quality of salted pegagan duck eggs using palm oil fronds ash and liquid smoke)

\begin{tabular}{|c|c|c|c|c|c|}
\hline \multirow{2}{*}{$\begin{array}{l}\text { Variabel } \\
\text { (variable) }\end{array}$} & \multicolumn{5}{|c|}{ Perlakuan (treatment) } \\
\hline & Ro & R1 & $\mathrm{R} 2$ & R3 & $\mathrm{R} 4$ \\
\hline $\begin{array}{l}\text { Warna kuning telur (yolk } \\
\text { color) }\end{array}$ & $13,58 \pm 0,63$ & $12,50 \pm 0,33$ & $12,50 \pm 0,96$ & $12,58 \pm 1,00$ & $12,00 \pm 0,94$ \\
\hline $\begin{array}{l}\mathrm{pH} \text { kuning telur }(\text { yolk } \\
\mathrm{pH})^{\mathrm{ns}}\end{array}$ & $7,27 \pm 0,09$ & $7,28 \pm 0,19$ & $7,19 \pm 0,09$ & $7,03 \pm 0,23$ & $7,02 \pm 0,13$ \\
\hline $\begin{array}{l}\mathrm{pH} \text { putih telur (albumen } \\
\mathrm{pH})^{\mathrm{s}}\end{array}$ & $9,58 \pm 0,10^{c}$ & $9,38 \pm 0,18^{b}$ & $9,32 \pm 0,05^{b}$ & $9,37 \pm 0,04^{b}$ & $9,13 \pm 0,09^{a}$ \\
\hline $\begin{array}{l}\text { Tebal kerabang }(\mathrm{mm}) \\
(\text { eggshell thickness } \\
(\mathrm{mm}))^{\mathrm{s}}\end{array}$ & $0,36 \pm 0,02^{\mathrm{a}}$ & $0,36 \pm 0,04^{a}$ & $0,36 \pm 0,01^{a}$ & $0,27 \pm 0,03^{b}$ & $0,25 \pm 0,03^{b}$ \\
\hline $\begin{array}{l}\text { Kedalaman rongga } \\
\text { udara }(\mathrm{mm})(\text { depth of air } \\
\text { cavity }(\mathrm{mm}))^{\mathrm{s}}\end{array}$ & $11,45 \pm 2,78^{b}$ & $8,68 \pm 1,00^{a}$ & $8,43 \pm 0,77^{a}$ & $8,61 \pm 0,96^{a}$ & $8,24 \pm 0,62^{a}$ \\
\hline 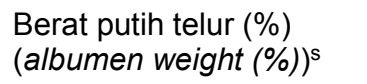 & $49,46 \pm 1,71^{a}$ & $56,09 \pm 6,10^{b}$ & $55,42 \pm 1,18^{b}$ & $51,36 \pm 1,66^{a b}$ & $51,30 \pm 1,66^{a b}$ \\
\hline $\begin{array}{l}\text { Berat kuning telur (\%) } \\
(\text { yolk weight }(\%))^{\text {ns }}\end{array}$ & $26,84 \pm 1,78$ & $25,75 \pm 0,76$ & $26,64 \pm 0,96$ & $26,94 \pm 1,76$ & $25,98 \pm 2,64$ \\
\hline $\begin{array}{l}\text { Berat kerabang telur (\%) } \\
(\text { eggshell weight }(\%))^{\mathrm{s}}\end{array}$ & $10,24 \pm 0,16^{b}$ & $10,47 \pm 0,42^{b}$ & $10,01 \pm 0,48^{a b}$ & $9,95 \pm 0,31^{a b}$ & $9,45 \pm 0,32^{a}$ \\
\hline $\begin{array}{l}\text { Indeks kuning telur (yolk } \\
\text { index })^{\text {ns }}\end{array}$ & $0,80 \pm 0,02$ & $0,77 \pm 0,02$ & $0,76 \pm 0,03$ & $0,74 \pm 0,01$ & $0,76 \pm 0,04$ \\
\hline  & $0,075 \pm 0,00^{a}$ & $0,08 \pm 0,00^{\mathrm{b}}$ & $0,08 \pm 0,00^{a b}$ & $0,083 \pm 0,00^{a b}$ & $0,076 \pm 0,00^{a}$ \\
\hline Haugh unit $(\mathrm{HU})^{\mathrm{s}}$ & $19,38 \pm 1,48^{a}$ & $23,76 \pm 2,53^{b c}$ & $21,80 \pm 1,65^{\mathrm{abc}}$ & $21,17 \pm 2,90^{\mathrm{ab}}$ & $25,08 \pm 2,69^{c}$ \\
\hline $\begin{array}{l}\text { Susut bobot telur }(\%) \\
(\text { egg weight loss }(\%))^{s}\end{array}$ & $3,09 \pm 0,48^{b}$ & $2,60 \pm 1,28^{b}$ & $2,32 \pm 0,48^{b}$ & $1,19 \pm 0,71^{a}$ & $0,57 \pm 0,28^{a}$ \\
\hline $\begin{array}{l}\text { Voskositas putih telur } \\
\text { (dPas) (albumen } \\
\text { viscosity (dPas)) }\end{array}$ & $92,5 \pm 9,57^{a}$ & $111,25 \pm 9,46^{b}$ & $118,75 \pm 4,79^{\mathrm{bc}}$ & $126,25 \pm 6,29^{c}$ & $145,00 \pm 8,16^{d}$ \\
\hline $\begin{array}{c}0 \text { kontrol (control/without li } \\
2,5 \% \text { ), R2 = pengasinan de } \\
\text { cair 7,5\% (salting process } \\
\text { with liquid smoke 10\%). } \\
\text { b,c,d Superskrip yang berbed } \\
\text { the same column indicate } \\
\text { Signifikan (sianificant) }{ }^{\mathrm{ns}} \mathrm{nc}\end{array}$ & $\begin{array}{l}\text { yuid smoke), R1 } \\
\text { ngan asap cair } \\
\text { with liquid smo }\end{array}$ & $\begin{array}{l}\text { = pengasinan de } \\
5 \%(\text { salting proces } \\
\text { ke } 7,5 \%) \text {, dan } \mathrm{R} 4 \\
\text { ng sama menunj } \\
\text { ent }(P<0.05)) \text {. }\end{array}$ & $\begin{array}{l}\text { ngan asap cair } 2, \\
\text { s with liquid smok } \\
=\text { pengasinan de } \\
\text { akkan berbeda ny }\end{array}$ & $\begin{array}{l}\text { (salting process } \\
5 \%), \mathrm{R} 3=\text { pengasi } \\
\text { jan asap cair } 10 \% \\
(\mathrm{P}<0,05) \text { (differe }\end{array}$ & $\begin{array}{l}\text { with liquid smoke } \\
\text { inan dengan asap } \\
\text { (salting process } \\
\text { int superscripts at }\end{array}$ \\
\hline
\end{tabular}

rongga udara, berat putih telur, berat kerabang telur, $\mathrm{pH}$ putih telur, indeks putih telur, haugh unit (HU), dan susut bobot telur, akan tetapi tidak berpengaruh nyata $(P>0,05)$ terhadap warna kuning telur, $\mathrm{pH}$ kuning telur, berat kuning telur, dan indeks kuning telur.
Hasil sidik ragam menunjukkan bahwa pengasinan telur itik pegagan dengan menggunakan abu pelepah kelapa sawit dan larutan asap cair nyata $(P<0,05)$ mempengaruhi susut bobot telur. Susut bobot telur dengan pengasinan menggunakan larutan 
asap cair nyata $(P<0,05)$ lebih rendah dibandingkan dengan yang tanpa menggunakan asap cair/kontrol. Susut bobot telur yang paling rendah adalah pada telur yang diasinkan dengan konsentrasi asap cair $10 \%$ (P4), yaitu $0,57 \%$. Hal ini menunjukkan bahwa semakin tinggi konsentrasi asap cair yang digunakan dalam proses pengasinan, maka penurunan bobot telur semakin kecil. Bobot telur dapat dipertahankan selama proses pengasinan karena peranan senyawa kimia yang terkandung di dalam asap cair yang berfungsi sebagai pelapis telur sehingga dapat mengurangi proses penguapan. Hal ini seperti yang diungkapkan oleh Pszczola (1995) bahwa senyawa asam-asam organik dan fenol yang terkandung dalam asap cair dapat menyelubungi kerabang telur dan melindungi pori-pori kerabang telur sehingga penguapan gas dan air dari dalam telur dapat dihambat, sehingga bobot telur dapat dipertahankan.

Berat putih telur nyata $(P<0,05)$ dipengaruhi oleh perlakuan pengasinan dengan menggunakan asap cair dan abu pelepah kelapa sawit, akan tetapi tidak nyata $(P>0,05)$ mempengaruhi berat kuning telur. Hal ini menunjukkan bahwa penggunaan larutan asap cair hingga konsentrasi $10 \%$ mampu mempertahankan berat putih telur dalam proses pengasinan, namun belum mampu mempertahankan berat kuning telur. Susut berat putih telur dengan pengasinan menggunakan asap cair nyata $(P<0,05)$ lebih rendah dibandingkan susut berat putih telur tanpa menggunakan asap cair. Terjadinya penurunan berat putih telur mengindikasikan bahwa terjadinya proses penguapan air dan gas dari putih telur. Hal ini seperti yang diungkapkan oleh Wulandari (2004) bahwa selama penyimpanan telur terjadi proses penguapan dari dalam telur berupa air dan gas, seperti karbondioksida, amonia, nitrogen, dan hidrogen sulfida, sehingga dapat mempengaruhi kualitas telur.

Hasil penelitian menunjukkan bahwa berat dan tebal kerabang telur nyata $(P<0,05)$ dipengaruhi oleh perlakuan. Berat dan tebal kerabang telur dengan menggunakan larutan asap cair dalam proses pengasinan nyata $(P<0,05)$ lebih rendah dibandingkan dengan tanpa menggunakan asap cair. Hal ini menunjukkan bahwa semakin tinggi penggunaan konsentrasi asap cair, berat dan tebal kerabang telur akan semakin menurun. Terjadinya penurunan berat dan tebal berat kerabang telur diduga karena adanya aktifitas asam-asam organik yang terkandung di dalam asap cair yang mengikis kerabang sehingga akhirnya terjadi perubahan ketebalan. Berdasarkan hasil analisis kandungan senyawa kimia asap cair, diketahui bahwa terdapat beberapa asamasam organik, di antaranya Acetic acid (CAS) Ethylic acid (13,31\%), Formic acid (CAS) Bilorin (12,27\%), Propanedioic acid (CAS) Malonic acid (21,06\%).

Kedalaman rongga udara telur nyata $(\mathrm{P}<0,05)$ dipengaruhi oleh perlakuan. Kedalaman rongga udara telur yang diasinkan dengan menggunakan asap cair nyata $(P<0,05)$ lebih kecil dibandingkan dengan tanpa menggunakan asap cair. Hasil yang demikian sejalan dengan nilai susut bobot telur yang diperoleh, di mana susut bobot telur yang diberi perlakuan asap cair juga nyata lebih tinggi dibandingkan dengan tanpa asap cair. Antara bobot telur dan ukuran rongga udara memiliki keterkaitan. Wulandari (2004) menyatakan bahwa terjadinya penurunan bobot dan pembesaran rongga udara telur dikarenakan adanya penguapan air dan pelepasan gas, seperti $\mathrm{CO}_{2}, \mathrm{NH}_{3}, \mathrm{H}_{2}$, dan $\mathrm{H}_{2} \mathrm{~S}$ yang merupakan hasil degradasi bahanbahan organik.

Hasil sidik ragam menunjukkan bahwa perlakuan dengan menggunakan abu pelepah kelapa sawit dan asap cair dalam proses pengasinan nyata $(P<0,05)$ mempengaruhi indeks putih telur, akan tetapi tidak nyata $(P>0,05)$ mempengaruhi indeks kuning telur. Hal ini menunjukkan bahwa penggunaan asap cair sampai konsentrasi $10 \%$ sudah mampu mempertahankan indeks putih telur, akan tetapi tidak terhadap indeks kuning telur. Hasil uji lanjut menunjukkan bahwa indeks putih telur yang diasinkan dengan menggunakan asap cair nyata $(P<0,05)$ lebih tinggi dibandingkan yang tanpa menggunakan asap cair. Meskipun demikian, penggunaan asap cair harus dibatasi karena apabila semakin tinggi penggunaan konsentrasi asap cair, maka indeks putih telur akan semakin menurun. Indeks putih telur sangat ditentukan oleh ukuran panjang dan lebar putih telur. Semakin rendah nilai indeks putih telur berarti ukuran panjang dan lebar putih telur semakin membesar. Faktor utama yang menyebabkan ukuran putih telur semakin melebar adalah karena terjadi proses penguapan gas dan uap air dari dalam telur. Hal ini seperti yang diungkapkan oleh Stadelman dan Cotterill (1995) bahwa selama penyimpanan, terjadi penguapan $\mathrm{CO}_{2}$ dan 
$\mathrm{H}_{2} \mathrm{O}$ dari dalam telur yang dapat menimbulkan ikatan kompleks ovomucin-lysozime sehingga putih telur menjadi semakin encer. Asap cair yang digunakan dalam proses pengasinan ini berfungsi sebagai bahan pelapis telur yang dapat menghambat proses penguapan $\mathrm{CO}_{2}$ dan $\mathrm{H}_{2} \mathrm{O}$ selama proses penyimpanan, oleh karena itu nilai indeks putih telur masih dapat dipertahankan. Nilai indeks kuning telur asin pada penelitian ini lebih rendah dibandingkan dengan nilai indeks kuning telur asin dari penelitian Kusumawati et al. (2012), yaitu 0,98 , sedangkan rataan nilai indeks kuning telur dari hasil penelitian ini adalah 0,77.

Nilai viskositas putih telur itik pegagan nyata $(P<0,05)$ dipengaruhi oleh perlakuan. Hasil uji lanjut menunjukkan bahwa viskositas putih telur yang diasinkan menggunakan asap cair nyata $(P<0,05)$ lebih tinggi dibandingkan tanpa menggunakan asap cair. Hasil yang demikian karena asap cair dapat berfungsi sebagai bahan pelapis kerabang telur yang dapat melindungi pori-pori telur dari proses penguapan. Hal ini seperti yang diungkapkan oleh Winarno dan Koswara (2002) bahwa penggunaan bahan pelapis dapat mengurangi proses penguapan air dari dalam telur, di mana pori-pori kerabang telur menjadi tertutup. Jika proses penguapan bisa dihambat, maka viskositas putih telur dapat dipertahankan. Beberapa senyawa kimia yang berfungsi sebagai penyelubung dan pelindung pori-pori kerabang telur adalah fenol dan asam-asam organik (Pszczola, 1995). Asap cair yang digunakan dalam penelitian ini mengandung banyak asap organik, seperti asam asetat, asam format, dan asam propanedioat. Total keseluruhan asam organik dalam asap cair adalah sekitar $61,22 \%$, sementara senyawa fenol sekitar $5 \%$ (Tabel 1). Hasil analisis kandungan asam organik asap cair pada penelitian sejalan dengan pernyataan Mu et al. (2004) bahwa senyawa yang paling banyak terkandung dalam asap cair adalah asam-asam organik, yaitu sekitar $60 \%$.

Hasil menunjukkan bahwa proses pengasinan dengan menggunakan abu pelepah sawit dan larutan asap cair berpengaruh nyata $(\mathrm{P}<0,05)$ terhadap $\mathrm{pH}$ putih telur, akan tetapi berpengaruh tidak nyata $(\mathrm{P}>0,05)$ terhadap $\mathrm{pH}$ kuning telur. Adapun rataan nilai $\mathrm{pH}$ kuning telur adalah 7,16 . Hasil uji lanjut menunjukkan bahwa $\mathrm{pH}$ putih telur yang diasinkan tanpa meng-gunakan asap cair nyata $(P<0,05)$ lebih tinggi dibandingkan dengan menggunakan asap cair. Stadelman dan Cotterill (1995) menyatakan bahwa faktor yang me-nyebabkan terjadinya peningkatan $\mathrm{pH}$ telur adalah karena adanya interaksi antara ovomucin dan lysozyme yang menyebabkan putih telur menjadi semakin encer. Semakin tinggi nilai $\mathrm{pH}$ putih telur, maka kondisi putih telur akan semakin encer. Sejalan dengan hal ini, Harahap (2007) dan Hajrawati (2012) menyatakan bahwa pada saat terjadi penguapan, gas $\mathrm{CO}_{2}$ akan ikut terbuang. Hal ini kemudian akan menurunkan ion karbonat sehingga akan mengganggu sistem buffer dan akhirnya akan meningkatkan nilai $\mathrm{pH}$. Hasil yang didapatkan ini sejalan dengan nilai viskositas putih telur yang diperoleh, di mana viskositas putih telur yang diasinkan dengan asap cair lebih tinggi dibandingkan dengan tanpa asap cair, sehingga $\mathrm{pH}$ telur juga lebih rendah. $\mathrm{pH}$ putih telur yang paling tinggi terletak pada perlakuan kontrol tanpa asap cair, yaitu 9,58, sementara $\mathrm{pH}$ putih telur yang paling rendah terletak pada perlakuan P4 dengan penambahan larutan asap cair $10 \%$, yaitu 9,13 .

Nilai haugh unit (HU) telur nyata $(P<0,05)$ dipengaruhi oleh perlakuan. Hasil uji lanjut menunjukkan bahwa nilai HU telur yang diasinkan tanpa asap cair nyata lebih rendah dibandingkan dengan yang menggunakan asap cair. Lebih lanjut, nilai HU telur pada perlakuan dengan konsentrasi asap cair tertinggi $(10 \%)$ terlihat lebih besar dibandingkan dengan perlakuan lainnya. Hal ini dikarenakan semakin tinggi konsentrasi asap cair yang digunakan maka senyawa kimia yang dapat terserap untuk melapisi permukaan kerabang telur akan semakin banyak. Hal ini sejalan dengan pendapat Dwidjoseputro (2005) bahwa tinggi rendahnya penyerapan suatu zat tergantung pada konsentrasi dan lamanya terkena zat tersebut. Komponen utama yang menentukan nilai HU adalah berat telur dan tinggi albumin tebal (thick albumin). Semakin besar nilai berat telur dan tinggi albumin, maka nilai HU semakin tinggi (Kusumawati et al., 2012). Hal ini berarti kualitas telur juga akan semakin baik. Nilai HU yang paling tinggi terletak pada proses pengasinan dengan larutan asap cair $10 \%$ yaitu 25,08 , sedangkan yang terendah terletak pada perlakuan kontrol (larutan asap cair $0 \%$ ), yaitu 19,38.

Hasil sidik ragam menunjukkan bahwa warna kuning telur tidak nyata $(P>0,05)$ 
dipengaruhi oleh perlakuan. Hal ini menunjukkan bahwa proses pengasinan dengan menggunakan larutan asap cair hingga konsentrasi $10 \%$ tidak menyebabkan perubahan warna pada kuning telur. Kusumawati et al. (2012) menyatakan bahwa salah satu faktor yang mempengaruhi perubahan warna kuning telur selama proses pengasinan adalah lamanya pemeraman. Sejalan dengan hal ini, Prihantari et al. (2010) menyatakan bahwa semakin lama proses pemeraman, maka air yang ditarik oleh ion garam akan semakin banyak. Hal ini akan membuat warna yang ada pada suatu bahan menjadi semakin pekat. Pada penelitian ini, lama yang digunakan untuk pemeraman telur itik adalah sama, yaitu 14 hari, oleh karena itu warna kuning telur juga tidak berbeda nyata. Adapun rataan warna kuning telur pada penelitian ini adalah 12,63.

\section{Kesimpulan}

Berdasarkan hasil penelitian dapat disimpulkan bahwa penggunaan abu pelepah kelapa sawit dan asap cair dalam proses pengasinan dapat mempertahankan kualitas fisik telur asin itik pegagan.

\section{Ucapan Terima Kasih}

Ucapan terima kasih disampaikan kepada Rektor Universitas Sriwijaya dan Ketua Lembaga Penelitian Universitas Sriwijaya yang telah memberikan bantuan dana melalui skim Penelitian Sains, Teknologi, dan Seni tahun 2015.

\section{Daftar Pustaka}

AOAC. 1984. Official Methods of The Accociation of Official Agriculture Chemist. AOAC. Inc. $14^{\text {th }}$ edn. Washington.

Dwidjoseputro. 2005. Dasar-dasar Mikrobiologi. Penerbit Djambatan, Jakarta.

Hajrawati, J. C. Likadja, dan Hessy. 2012. Pengaruh lama perendaman ekstrak kulit buah kakao dan lama penyimpanan terhadap daya awet telur ayam ras. Agriplus 22: 43-49.

Harahap, E. U. 2007. Kajian pengaruh bahan pelapis dan teknik pengemasan terhadap perubahan mutu telur ayam buras selama transportasi dan penyimpanan. Tesis Institut Pertanian Bogor, Bogor.

Iza, A. L., F. A. Garhner and B. Meller. 1985. Effect of egg and season of the year on egg quality. 1. Shell Quality. Poult. Sci. 64: 1900-1906.

Jazil, N., A. Hintono, dan S. Mulyani. 2013. Penurunan kualitas telur ayam ras dengan intensitas warna coklat kerabang berbeda selama penyimpanan. Jurnal Aplikasi Teknologi Pangan 2: 43-47.

Kusumawati E., M. D. Rudyanto, dan I. K. Suada. 2012. Pengasinan mempengaruhi kualitas telur itik Mojosari. Indonesia Medicus Veterinus 1: 645656.

Mu, J., T. Uehara and T. Furuno. 2004. Effect of bamboo vinegar on regulation ofgermination and radical growth of seed plants II: composition of Mosobamboo vinegar at different collection temperature and its effects. J. Wood Sci. 50: 470-476.

Nursiwi, A., P. Darmadji, S. Kanoni. 2013. Pengaruh penambahan asap cair terhadap sifat kimia dan sensoris telur asin rasa asap. Jurnal Teknologi Hasil Pertanian 6: 82-89.

Prihantari, M. Wijanarka, A. dan Siswati, T. 2010. Pengaruh lama perendaman abu pelepah kelapa terhadap sifat fisik, organoleptik, daya simpan dan kadar kalsium telur asin. Skripsi Politeknik Kesehatan Yogyakarta Jurusan Gizi, Yogyakarta.

Pszczola, D. E. 1995. Tour highlight production and uses of smoke based flavors. Food Tech. 49: 70-74.

Ramanoff, A. L. and A. J. Ramanoff. 1963. The Avian Egg. The $2^{\text {nd }}$ edn. Jhon Wiley and Sons, New York.

Sihombing, G., Avivah, dan S. Prastowo. 2006. Pengaruh penambahan zeolit dalam ransum terhadap kualitas telur burung puyuh. J. Indon. Trop. Anim. Agric. 31: 28-31.

Sirait, C. H. 1986. Telur dan Pengolahannya. Pusat Penelitian dan Pengembangan Peternakan, Bogor.

Stadelman, W. J. and O. J. Cotterill. 1995. Egg Science and Technology. The $4^{\text {th }}$ edn. Food products Press. An Imprint of the Haworth Press, New York. 
Steel, R. G. D. dan J. H. Torrie. 1993. Prinsip dan Prosedur Statistika. Edisi ke-2. Penerjemah Bambang Sumantri. Gramedia Pustaka Utama, Jakarta.

Winarno, F. G. dan S. Koswara. 2002. Telur: Komposisi, Penanganan, dan Pengolahannya. M. Brio Press, Bogor.

Wulandari, Z. 2004. Sifat fisikomia dan total mikroba telur itik asin hasil teknik perendaman dan lama penyimpanan yang berbeda. Media Peternakan 27: 38-45.
Yosi, F., S. Sandi, dan N. Afridayanti. 2015. Pengaruh penggunaan asap cair dan lama penyimpanan terhadap kualitas telur Itik Pegagan. Jurnal Peternakan Sriwijaya 4: 20-27.

Yulistiani, dan D. Purnama. 1997. Kemampuan penghambatan asap cair terhadap pertumbuhan bakteri patogen dan perusak pada lidah sapi. Tesis Universitas Gadjah Mada, Yogyakarta. 